\title{
Serum lysozyme in inflammatory bowel and coeliac disease
}

\author{
E. MAllas, J. M. TERRY, P. ASQUith, AND W. T. COOKE
}

From The Nutritional and Intestinal Unit, The General Hospital, Birmingham, the MRC Renal Research Unit, Queen Elizabeth Hospital, Medical Centre, Birmingham, and the Department of Experimental Pathology Birmingham University

SYNOPSIS Serum lysozyme levels were determined by a turbidometric method using egg white त $_{0}$ lysozyme as standard in 100 patients with Crohn's disease, 86 with ulcerative colitis, 31 with coeliac $v$ disease, and in 38 normal control subjects. Though the levels in Crohn's disease were significantly $\mathbb{D}_{\infty}$ higher than those in ulcerative colitis and in coeliac disease, there was marked overlap between the ${ }_{0}$ disorders and control subjects, and so they were of no value in differential diagnosis. There was some $\rightarrow$ evidence that serum lysozyme levels reflected disease activity in Crohn's disease but not in ulcerative $\subseteq$ colitis.

Lysozyme was originally described by Fleming (1922), who also noted that certain bacteria, and particularly Micrococcus lysodeikticus, were sensitive to the action of lysozyme. It is a basic protein with a low molecular weight which functions as a mucolytic enzyme breaking down aminopolysaccharides in cell walls of bacteria (Salton, 1957). Strong lysozyme activity has been found in tears, sputum, and nasal, gastric, and intestinal secretions, whereas saliva and serum exhibit relatively little activity (Fleming, 1922; Thompson, 1940). In the tissue bone marrow, lungs, intestines, spleen, and kidneys have been reported to have the greatest lysozyme concentrations (Florey, 1930; Perri et al, 1964; Hansenetal, $1969,1971)$. Among the cells, lysozyme occurs in relatively high concentrations in granulocytes and monocytes (Briggs et al, 1966; Asamer et al, 1971), from which most of the enzyme probably derives (Finch et al, 1964; Lippman and Finch, 1972).

Serum lysozyme activity has been found to be increased in myeloproliferative disorders with increased granulocyte turnover (Osserman and Lawlor, 1966; Skarin et al, 1972), in megaloblastic anaemia (Perillie et al, 1967), acute bacterial infections, and leukaemoid reactions. Increased values have been found in patients with severe renal impairment (Niwa et al, 1974). Raised serum levels have also been reported in cases of granulomatous disease such as tuberculosis (Perillie et al, 1973) and sarcoidosis (Pascual et al, 1973).

Received for publication 17 December 1975
Recently Falchuk et al (1975a) claimed that serum lysozyme activity differentiates between Crohn's disease and ulcerative colitis, an important observation in view of the many difficulties that exist in differentiating these two disorders (Kirsner, 1975). $\frac{\mathrm{Q}}{\mathrm{D}}$ Furthermore, Falchuk et al (1975b) suggested that $\stackrel{\varrho}{\overrightarrow{1}}$ serum levels may serve as an index of activity and were thus of value in monitoring the course and response to treatment. The majority of methods measuring disease activity have been based on the arbitrary evaluation of symptoms and clinical examination (Edwards and Truelove, 1963; Kane, et al, 1974; Lennard-Jones et al, 1975), though there are an increasing number of reports on the $\delta$ use of laboratory measurements. The purpose of 3 this paper is to evaluate the validity of the claims 을 put forward by Falchuk and his colleagues.

\section{Clinical material and methods}

One hundred patients with regional enteritis, $86 \stackrel{N}{\circ}$ with ulcerative colitis, and 31 with coeliac disease attending the Nutritional and Intestinal Unit formed the patient group, the diagnosis being based upon accepted criteria (Schachter and Kirsner, 1975; Cooke and Asquith, 1974). Thirty-eight controls $\stackrel{\oplus}{?}$ were drawn from hospital doctors, laboratory 0 personnel, and nurses free from intercurrent infection or symptoms of intestinal disease.

Serum lysozyme activity was determined by an $\frac{\overrightarrow{\mathbb{Q}}}{\stackrel{Q}{2}}$ automated modification by Terry et al (1971) of the $\frac{\varrho}{\sigma}$ manual method of Smolelis and Hartsell (1949) 
based on the change in turbidity of cell suspensions of killed and lyophilized $M$. lysodeikticus using egg white lysozyme as reference standard. Serum was separated within one hour of withdrawal, stored at $-20^{\circ} \mathrm{C}$, and assayed at differing times between one and four weeks later. Aliquots from 10 samples assayed at weekly intervals failed to demonstrate any significant change over this period of time.

Haemoglobin, serum albumin, and seromucoid levels were used as indicators of disease activity (Cooke et al, 1958; Dearing et al, 1969; Cooke, 1972; Marner et al, 1975) and were correlated with serum lysozyme values to test its validity for this purpose.

\section{Results}

The mean serum lysozyme values and standard deviations found in control subjects, in Crohn's disease, ulcerative colitis, and in coeliac patients are shown in the figure. Though there was overlap between all groups the results in Crohn's disease were significantly different from those in ulcerative colitis, coeliac disease, and in control subjects ( $\mathrm{P}<0.001,<0.025$, and $<0.001$ respectively). Values in ulcerative colitis and in coeliac disease were significantly different from those in control subjects $(\mathbf{P}<0.001)$ but not significantly different from each other.

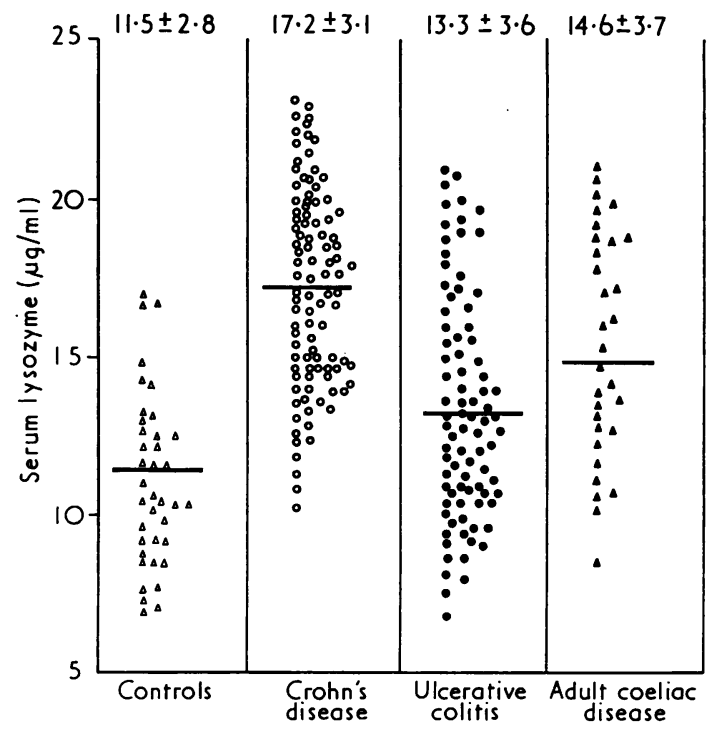

Figure Scattergram of lysozyme levels in normal subjects and in patients with Crohn's disease, ulcerative colitis, and adult coeliac disease together with mean levels and standard deviation in each group.
There were significant correlations $(P<0.001)$ in both Crohn's disease and ulcerative colitis between seromucoids and albumin, albumin and haemoglobin, and seromucoids and haemoglobin. Lysozyme values in Crohn's disease correlated significantly with serum seromucoid levels $(P<0.001)$ but did not correlate in ulcerative colitis or with albumin or haemoglobin in either disease.

\section{Discussion}

Falchuk et al (1975a), using a lysoplate method with purified human lysozyme as standard, demonstrated a clearcut difference without overlap between the serum lysozyme values of Crohn's disease and those of ulcerative colitis. This, from the results in a larger group of patients with Crohn's disease subsequently reported by them (Falchuk et al, 1975b) in which the levels in inactive Crohn's disease were not significantly different from those in ulcerative colitis, may have been due to the inclusion of more patients with severe disease activity in Crohn's disease than in ulcerative colitis. Peeters et al (1975), on the other hand, found no significant differences between the serum levels in these disorders using egg white lysozyme as standard, which may not be as sensitive as purified human lysozyme (Osserman and Lawlor, 1966). Pounder et al (1975) reported results similar to those in this paper, mean levels of lysozyme in Crohn's disease being significantly greater than those in ulcerative colitis with considerable overlap of values in the two disorders.

Lysozyme appears to be continuously released from macrophages independent of phagocytosis or stimulation and hence reflects the total body pool of macrophages (Gordon et al, 1974). Mason and Taylor (1975) demonstrated that lysozyme staining reactions in epithelioid histiocytes in Crohn's disease were strongly positive. However, among our patients high serum levels did not correlate with extensive disease nor low levels with extensive surgical resection. It has also been noted that there are considerable amounts of lysozyme in Paneth cells (Klockars and Osserman, 1974) and this might be the explanation of the raised values in coeliac disease. Such findings underline the nonspecific nature of serum lysozyme levels in intestinal disorders. In this clinic serum albumin and serum seromucoids have been estimated routinely since 1955 as indicators of disease activity in the care and followup of patients with inflammatory bowel disease (Cooke et al, 1958; Cooke, 1972). The correlation between seromucoids and lysozymes in Crohn's disease (though not in ulcerative colitis) in the present survey offers support to the suggestion of Falchuk et al (1975b) that serum lysozyme 
estimations provide a useful index of disease activity. However, despite this statistical correlation, there were sufficient patients clinically ill with low serum albumins, high seromucoids, and low lysozyme levels to make reliance on serum albumin and serum seromucoid levels preferable as indicators of disease activity.

In conclusion, we have been unable to confirm serum lysozyme determinations as aids in the differential diagnosis between Crohn's disease and ulcerative colitis but they may be a measurement of some value additional to serum albumin and seromucoid in assessing disease activity in Crohn's disease though not in ulcerative colitis.

\section{References}

Asamer, H., Schmalzl, F., and Braunsteiner, H. (1971). Immunocytological demonstration of lysozyme (muramidase) in human leukaemic cells. Brit. J. Haemat., 20, 571-574.

Briggs, R. S., Perillie, P. A., and Finch, S. C.(1966). Lysozyme in bone marrow and peripheral blood cells. J. Histochem. Cytochem., 14, 167-170.

Cooke, W. T. (1972). Survey of results of treatment of Crohn's disease. Clin. Gastroent., 1, 521-531.

Cooke, W. T. and Asquith, P, (1974). Introduction and definition. Clin. Gastroenterol., 3, 3-10.

Cooke, W. T., Fowler, D. I., Cox, E. V., Gaddie, R., and Meynell, M. J. (1958). The clinical significance of seromucoids in regional ileitis and ulcerative colitis. Gastroenterology, 34, 910-919.

Dearing, W. H., McGuckin, W. F., and Elveback, Lila R. (1969). Serum A-acid glycoprotein in chronic ulcerative colitis. Gastroenterology, 56, 295-303.

Edwards, F. C. and Truelove, S. C. (1963). The course and prognosis of ulcerative colitis. Gut, 4, 299-308.

Falchuk, K. R., Perrotto, J. L., and Isselbacher, K. J. (1975a). Serum lysozyme in Crohn's disease and ulcerative colitis. New Engl.J. Med., 292, 395-397.

Falchuk, K. R., Perrotto, J. L., and Isselbacher, K. J. (1975b). Serum lysozyme in Crohn's disease: a useful index of disease activity. Gastroenterology, 69, 893-896.

Finch, S. C., Lamphere, J. P., and Jablon, S. (1964). The relationship of serum lysozyme to leucocytes and other constitutional factors. Yale J. biol. Med., 36, 350-360.

Fleming, A. (1922). On a remarkable bacteriolytic element found in tissues and secretions. Proc. roy. Soc. B., 93, 306-317.

Florey, H. (1930). The relative amounts of lysozyme present in the tissues of some mammals. Brit. J. exp. Path., 11, 251-261.

Gordon, S., Todd, J., and Cohn, Z. A. (1974). In vitro synthesis and secretion of lysozyme by mononuclear phagocytes. J. exp. Med., 139, 1228-1248.

Hansen, N. E., Karle, H., and Andersen, V. (1969). Muramidase activity of bone marrow plasma. Studies in haematologically normal individuals and in granulocytopenic patients. Acta med. scand., 185, 387-392.

Hansen, N. E., Karle, H., and Andersen, V. (1971). Lysozyme turnover in the rat. J. clin. Invest., 50, 1473-1477.

Kane, S. P., Hoff brand, A. V., Neale, G. N. (1974). Indices of granulocyte activity in inflammatory bowel disease GUT, 15, 953-959.

Kirsner, J. B. (1975). Problems in the differentiation of ulcerative colitis and Crohn's disease of the colon: the need for repeated diagnostic evaluation. Gastroenterolog 68, 187-191.

Klockars, M. and Osserman, E. F. (1974). Localisation o lysozyme in normal rat tissues by an immunoperoxidase method. J. Histochem. Cytochem., 22, 139-146.

Lennard-Jones, J. E., Ritchie, Jean K., Hilder, W., and Spicer? C. C. (1975). Assessment of severity in colitis. A preliminaro study. Gut, 16, 579-584.

Lippman, M. E. and Finch, S. C. (1972). A quantitative stud $\vec{P}$ of muramidase distribution in normal and nitroge $\overline{\mathrm{C}}$ mustard-treated rats. Yale J. biol. Med., 45, 463-470.

Marner, I. L., Friborg, S., and Simonsen, E. (1975). Diseas activity and serum proteins in ulcerative colitis. Immunof chemical quantitation. Scand. J. Gastroent., 10, 537-544. i

Mason, D. Y. and Taylor, C. R. (1975). The distribution off muramidase (lysozyme) in human tissues. J. clin. Path., 28, 124-132.

Niwa, T., Ito, T., Matsui, E., and Ohta, H. (1974). Serumpo and urinary lysozyme activities in patients with renas diseases. Tohoku J. exp. Med., 114, 27-33.

Osserman, E. F. and Lawlor, D. P. (1966). Serum and urinary lysozyme (muramidase) in monocytic and monomyelo cytic leukemia. J. exp. Med., 124, 921-951.

Pascual, R. S., Gee, J. B. L., and Finch, S. C. (1973). Usefuto ness of serum lysozyme measurement in diagnosis and evaluation of sarcoidosis. New Engl. J. Med., 289, 1074-1076.

Peeters, T. L., Geboes, K., and Vantrappen, G. R. (1975) Serum lysozyme levels in Crohn's disease. (Letter. Witt reply by Falchuk et al.). New Engl.J. Med., 292, 1349-1350̄

Perillie, P. E., Kaplan, S. S., and Finch, S. C. (1967) Significance of changes in serum muramidase activity if megaloblastic anaemia. New Engl. J. Med., 277, 10-12.

Perillie, P. E., Khan, K., and Finch, S. C. (1973). Serum lysozyme in pulmonary tuberculosis. Amer. J. med. Sci 265, 297-302.

Perri, G. C., Faulk, M., Shapiro, E., and Money, W. (1964). Role of the kidney in accumulation of egg white muramidase in experimental animals. Proc. Soc. exp. Bio (N.Y.), 115, 189-192.

Pounder, R. E., Avella, J. R., McCallum, H., and Misiewic J. J. (1975). Serum lysozyme in inflammatory bowe disease. (Letter). Lancet, $2,228$.

Salton, M. R. J. (1957). The properties of lysozyme and its action on micro organisms. Bact. Rev., 21, 82-99.

Schackter, H. and Kirsner, J. B. (1975). Definitions of in flammatory bowel disease of unknown aetiology. Gastro $\$$ enterology, 68, 591-600.

Skarin, A. T., Matsuo, Y., and Moloney, W. C. (1972) Muramidase in myeloproliferative disorders terminatine in acute leukemia. Cancer (Philad.), 29, 1336-1342.

Smolelis, A. N. and Hartsell, S. E. (1949). The determination

of lysozyme. J. Bact., 58, 731-736.
Terry, J. M., Blainey, J. D., and Swingler, M. C. (1971). automated method for lysozyme assay. Clin. chim. Acta, 35, 317-320.

Thompson, R. (1940). Lysozyme and its relation to the antibacterial properties of various tissues and secretions Arch. Path, 30, 1096.

Requests for reprints to: W. T. Cooke, The Genera्ष Hospital, Birmingham B4 6NH. 